\title{
Sixth-Grade Students' Procedural and Conceptual Understandings of Division Operation in a Real-Life Context
}

\author{
Lütfi İncikabıa , Perihan Ayanoğlu ${ }^{b}$, Ramazan Uysal ${ }^{* 0}$
}

\author{
Received \\ Revised \\ Accepted \\ $\mathrm{DOl}$ \\ 24 April 2020 \\ 30 June 2020 \\ 3 September 2020 \\ 10.26822 /iejee. 2020.171 \\ Lütfi İncikabı. Department of Mathematics and \\ Science Education, Faculty of Education, \\ Kastamonu University, Kastamonu, Turkey. \\ E-Mail: lincikabi@kastamonu.edu.tr \\ ORCID: https://orcid.org/0000-0002-7912-780X \\ perihan Ayanoğlu. Department of Mathematics \\ and Science Education, Faculty of Education \\ Kastamonu University, Kastamonu, Turkey. \\ E-Mail: perihanayanoglu@gmail.com \\ ORCID: https://orcid.org/0000-0002-3798-9671 \\ Corresponding Author: Ramazan Uysal. \\ Department of Mathematics and Science \\ Education, Faculty of Education, Kastamonu \\ University, Kastamonu, Turkey. \\ E-Mail: ramzanuysal32@gmail.com \\ ORCID: https://orcid.org/0000-0002-8426-717X
}

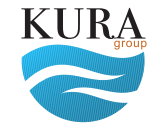

Copyright (c)

WWw.iejee.com

ISSN: 1307-9298

(c) 2020 Published by KURA Education \& Publishing. This is an open access article under the CO BY- NC- ND license. (https://creativecommons. org/licenses/by/4.0/)

\begin{abstract}
This study aimed to reveal the conceptual and operational conceptions of sixth-grade students in the process of division. The focus of the study included the strategies used in the division process, the students' understanding of the division algorithm, and their ability to interpret the remainder in a real-life context. Being qualitative in nature, the current study adopted the case study methodology. The sample of the study consisted of 64 sixth-grade students studying at two middle schools in the province of Kastamonu, Turkey in the 2018-2019 academic year. The data collection tool was a test consisting of five open-ended questions presented to the students. According to the research findings, while most of the students used the division operation in problemsolving, some students used different strategies, such as multiplication, addition, subtraction, and mental calculation. The majority of the students using the division algorithm were successful in applying the steps of the division operation but had difficulty in interpreting the remainder. In this research, it was also seen that the students had difficulties regarding the use of zero as a placeholder in the division operation. The students also encountered more difficulty in the division problems requiring the use of zeros in the last digits of the quotient than using zeros in other digits of the quotient.
\end{abstract}

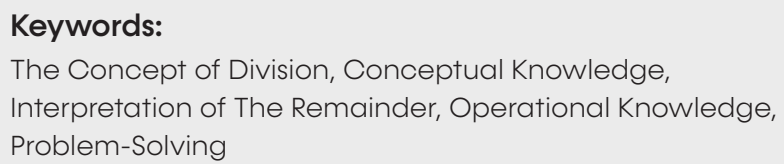

\section{Introduction}

athematics subjects have a strong sequential structure Vdue to the consecutive and cumulative structure of mathematics (Altun, 2015). Learning new subjects is related to previously acquired skills (Önal \& Aydın, 2018). The four operations of consecutive addition, subtraction, multiplication, and division comprise one of the basic skills and are very important in the mathematics learning process (Ev-Çimen \& Tat, 2018). Learning this skill without errors affects the future learning experiences of individuals, and therefore it is important to identify and eliminate misconceptions and errors related to this skill at an early stage (Yorulmaz, 2018). 


\section{iejee}

The four operations should be carried out in a specific order (Haskell, Pillay \& Steinhorn, 2000). Many students and teachers have difficulty in understanding the concept of division (Horton, 2007). Capps (1962) stated that regardless of which method was used, some arithmetic operations were more difficult to teach to children than other operations, and he emphasized that it was generally accepted that the most difficult of the four basic processes was division. Even if the numbers are small, the division process is more difficult for students (Brown, 1981).

Cornu (1991) suggested that students might have difficulty in understanding the concepts and adopt misconceptions which can be categorized as based on epistemological, psychological, and pedagogical aspects. Epistemological difficulties arise from the nature of the concept itself. From this point of view, the concept of division difficulty is related not only to two different procedures, such as being fragmented on grouped division but also the necessity of multiplication, addition, and subtraction as well as estimation in the process (Anghileri, 2001; Camos \& Baumer, 2015). Division is introduced to children as an arithmetic operation based on the prior knowledge of addition, subtraction, and multiplication (Parmar, 2003). Therefore, how well children learned the previous algorithms can affect their performance in division (Robinson, Arbuthnott, Rose, McCarron, Globa, \& Phonexay, 2006). When using the division algorithm, students must consider the maximum number that will produce a result equal to or less than the size represented by the corresponding digits in the division, and finding the maximum possible product is almost always an obstacle for children who may not be aware of the virtual product (Leung, Wong, \& Pang, 2006). According to Lee (2007), the traditional division algorithm is a known example that students have difficulty in understanding because of their differences in other algorithms. Unlike other processes in this algorithm, the division process starts from the left or the big digit (Fuson, 2003; VanDe Walle, 2001). Besides, even though division and multiplication are inverses, the use of the remainder makes division much more difficult than multiplication (Pope, 2012).

Cornu (1991) referred to pedagogical difficulty commenting on the problems experienced by students which can be caused by the teaching method and the content. Although the division process has been taught in schools since the elementary years, the conceptual aspects of the division process and the mathematical meaning underlying the process is not taught to the students (Silver \& Burkett, 1994); thus a student can undertake division correctly without knowing the basic meaning of division (Leung et al., 2006). In general, procedural instruction leaves behind the concepts of digit value in the previous processes (Martin Jr, 2009); therefore, students cannot make sense of the process (Sarwadi \& Shahrill, 2014). Kamii and Dominick (1997) emphasized that stereotyped algorithm teaching and overemphasis on this method restricted increasing students' understanding of number relations. Also, Khan (2004) stated that overemphasis on algorithm memorization techniques made it difficult for students to think about the problem and check the appropriateness of their solutions. In his study, Ebby (2005) stated that rote algorithms prevented children from understanding the concept of digit value and more generally the development of the sense of number. When this sense does not develop, the general understanding of numbers and transactions cannot be applied in flexible ways to develop useful strategies (Mclntosh, Reys, \& Reys, 1992). Many children constantly perform the subtraction and division of numbers throughout the process, but they do not know the reason why they perform subtraction in a certain order (Leung et al., 2006). For example, while they write the remainder of the ones digit in the first step, they move to the tens digit in the second step (Leung et al., 2006). The subtraction in the division process is not complete because the role of the other digits is neglected; thus, this subtraction surprises the students concerning the digit value (Leung et al., 2006).

Knowing what to do with the rest of the questions that require division is also a key element of generating a solution to the problem (Horton, 2007). The correct solution of residual division problems requires not only the correct execution of a division calculation, but also the correct interpretation of the calculation results according to a particular problem situation (Cai \& Silver, 1995; Silver, Shapiro, \& Deutsch, 1993). Depending on the problem situation, the remainder may need to be expressed as integers, fractions, or decimals (Horton, 2007). One of the biggest problems with division, according to Pope (2012), is to interpret the answer if the calculation result is not an integer. The successful interpretation of the remainder of the process depends on the understanding of the content and the quantities given, and the process for the solution can serve as a computational model for each problem case with different answers. For example, Silver, Mukhopadhyay and Gabriele (1992) identified the following three types of questions that could be solved using the same division process based on the statement: "Mary has 100 cakes to put in containers, each with 40 cakes. (1) How many containers can be filled? (2) How many containers should be used for all cakes? (3) How many cakes remain after filling the container as much as possible?"

Silver et al. (1992) listed the problem situations that could be related to the same division process as follows:

a) augmented-quotient problem situations, where it is necessary to increase the quotient if a remainder occurs in the calculation. 
b) Quotient-only problem situations, where the right approach is to ignore the remainder.

c) remainder-only problem situations, where it is necessary to provide only the remainder as the solution, and

d) quotient-part situations, where a portion of the remaining components including factors and conditions is required to provide a single solution. For example, 13.5 (or 131/2) structures are given as an answer.

An understanding that has not developed the concepts of the division process sufficiently leads to unrealistic answers; i.e., conceptual obstacles (Greer, 1992; Silver et al., 1993), followed by unquestioning responses (Simon 1993). That is, the meaning in the context of a problem needs to be correctly evaluated and coordinated with the process. In their studies, Silver et al. (1993) reported that a successful solver who encountered a problem condition involving a splitting process returned the result of the transaction to the problem state and problem representation after performing the problemrelated process and that the appropriate response to the relevant state and expression could only be generated at the end of this process (Figure 1).

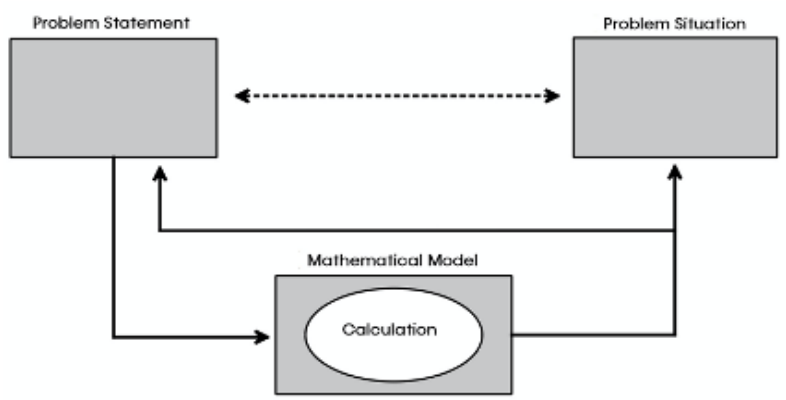

Figure 1. Schematic presentation of the correct solution of the division problem (Silver et al., 1993).

Silver (1988) and Silver et al. (1992) examined the performance of students in the types of division problems (e.g., augmented-quotient problems, remainder-only problems, and quotient-only problems). In particular, it was found that students can successfully be passed from the problem text to a mathematical model (division calculation), made the calculation correctly, but could not return to the problem story. In this respect, the wrong answers were given regarding the problem situations presented. Rodríguez, Lago, Hernández, Jiménez, Guerrero and Caballero (2009) emphasized that when students did not understand the problem, they provided answers that focused on the algorithm or the superficial knowledge of the problem.

Various studies are presenting the strategies used for division operations (Leung et al., 2006; Robinson, Arbuthnott, \& Gibbons, 2002; Robinson et al., 2006; Silver et al., 1993), as well as those that are related to the level of procedural-conceptual knowledge and reasoning skills for the concept of division (Ball, 1990; Ev-Çimen \& Tat, 2018; Horton, 2007; Kaasila, Pehkonen \& Hellinen, 2010; Lamb \& Booker 2004; Simon 1993; Yenilmez \& Dere, 2018). Horton (2007) propose some strategies for solving division problems including long division, multiplication, and repeated addition/subtraction. Long division is the method used most often to solve basic division problems, especially when dealing with numbers of two digits or more; multiplication reverses the process and requires working backwards towards the solution; the process of repeated subtraction involves beginning with the dividend and subtracting while repeated addition involves repeatedly adding the divisor multiple times until the divided is reached (Horton, 2007, p. 18). Besides using above strategies to attain the solutions in the division problems, the general understanding of division consists of remembering the rules and that few people can give mathematical explanations with the underlying basic principles and meanings (Ball, 1990; Horton, 2007; Kaasila et al., 2010).

In Turkey, studies on procedural and conceptual knowledge and reasoning skills are quite limited (Baki \& Bütün, 2009; Baki, 2013; Yenilmez \& Dere, 2018; Ev-Çimen \& Tat, 2018; Işık, Kar, Işık \& Albayrak, 2012; Varol \& Kubanç, 2015). The study conducted by Yenilmez and Dere (2018) revealed that the students were inadequate in interpreting their answers and accepted the quotient as an answer by ignoring the remainder in the division process. Besides, in a study by Varol and Kubanç (2015), it was observed that the students started the division process from the right (ones digit) by generalizing the rule applied to addition, subtraction, and multiplication. As with the addition and subtraction processes, it is a common problem for students to generalize the rule of conducting transactions between units and units, tens and tens digit into the division process. In another study, Baki (2013) reported that a significant number of the prospective classroom teachers did not understand the mathematical meaning of the algorithm related to the digit concept of the division process and their instructional explanations were insufficient. In an earlier study conducted by Baki and Bütün (2009) with mathematics teachers, it was found that the teachers did not emphasize the different meanings of the division concept and tried to teach the concept of division by rule and operation axis. The current study is important in terms of revealing the students' operational-conceptual knowledge of the division process, the strategies used, and the reasoning skills of the students. In this respect, it is considered to contribute to the related literature.

\section{Purpose of the Research}

The aim of this study was to reveal the conceptual and procedural understanding of sixth-grade students in the 


\section{iejee $\approx$}

division process. In this context, the study focused on the strategies used in the division process, the students' understanding of the division process, and their ability to interpret the remainder in a real-life context during the division process. For this purpose, the research problems that were investigated are listed below:

1. What strategies did students apply and how did they use them to solve long division problems and to what extent were they successful in interpreting the remainder in real-life situations?

2. What was the students' understanding of the division algorithm and use of zero in the division operation?

\section{Method}

\section{Research Model}

Being qualitative in nature, this was a case study, in which a researcher examines a situation within its context, limited by time and activity, and collects detailed information (Merriam 1998; Yin 2003). The case that was investigated in the current research involves sixth-grade students' understanding of the concept of division, the mistakes they make when applying the division algorithm, and their ability to establish a relationship between real-life situations and the division process.

\section{Study Group}

The participants in this study were the sixth-grade students of two middle schools in Kastamonu province located in the northern part of Turkey. A purposeful (deliberate) sampling method was used to determine the participants (Yıldırım \& Şimşek, 2005). The criteria for determining the grade level included the curriculum coverage of the objectives regarding division operations, and in this context, sixth-grade students were used as the targeted population. In determining the schools to be included, the provincial general achievement average was taken into account and two schools with an average level of achievement were included in the study. A total of 64 sixth-grade students (33 boys and 31 girls) volunteered to participate in the research. In the study, no harm occurred to the students.

\section{Data Collection Tools}

In the study, a test consisting of open-ended questions requiring division was applied to the sixth-grade students, and their written answers were examined. The questions in the test were prepared by a mathematics education specialist and two mathematics teachers.
Before its implementation, the validity of the test was checked by an external mathematics education expert.

Table 1 provides the specifications of the test items. The questions were prepared considering the objectives of "interpreting the remainder in case of problems related to division" and "divide a natural number with a maximum of four digits into a natural number with a maximum of two digits" in the middle school mathematics teaching program. The first three questions required the students to solve a real-life problem involving division with a remainder, and the strategies they used to solve the problems and their interpretation skills were examined. The fourth question involved performing two division operations related to the use of zero in the quotient. This question aimed to investigate the correct use of zeros in the division operation. In the fifth question, the students were presented with two incorrectly executed operations: the first required them to find the maximum quotient that would be taken from the corresponding digit(s) in the dividend, while the second required detecting the correct use of zero in the division operation.

Table 1. Test items and their specifications

\begin{tabular}{|c|c|c|c|c|}
\hline & \multicolumn{2}{|c|}{ Context } & Knowledge assessed & Units of analysis \\
\hline 1 & \multicolumn{2}{|c|}{ Real-life: } & $\begin{array}{l}\text { Augmented-quotient } \\
\text { problem situations (AQ): } \\
\text { Increasing quotient if a } \\
\text { remainder occurs in the } \\
\text { calculation. }\end{array}$ & $\begin{array}{l}\text { - Operation } \\
\text { strategies } \\
\text { - Procedural } \\
\text { fluency } \\
\text { - Interpreting } \\
\text { remainder }\end{array}$ \\
\hline 2 & \multicolumn{2}{|c|}{ Real-life } & $\begin{array}{l}\text { Quotient-only problem } \\
\text { situations (QO): Ignoring } \\
\text { remainder, only quo- } \\
\text { tient problem situations }\end{array}$ & $\begin{array}{l}\text { - Operation } \\
\text { strategies } \\
\text { - Procedural } \\
\text { fluency } \\
\text { - Interpreting } \\
\text { remainder }\end{array}$ \\
\hline 3 & \multicolumn{2}{|c|}{ Real-life } & $\begin{array}{l}\text { Quotient-part situation } \\
\text { (QP): Presenting remain- } \\
\text { der as a single structure } \\
\text { within the quotient (e.g. } \\
13.5 \text {, or } 13^{1 / 2} \text { ) }\end{array}$ & $\begin{array}{l}\text { - Operation } \\
\text { strategies } \\
\text { - Procedural } \\
\text { fluency } \\
\text { - Interpreting } \\
\text { remainder }\end{array}$ \\
\hline \multirow{2}{*}{4} & & $\begin{array}{l}\text { Pure } \\
\text { Mathematics }\end{array}$ & $\begin{array}{l}\text { Placing zeros in ones' } \\
\text { digit of the quotient }\end{array}$ & $\begin{array}{l}\text { - Correctness of } \\
\text { solution }\end{array}$ \\
\hline & $b$ & $\begin{array}{l}\text { Pure } \\
\text { Mathematics }\end{array}$ & $\begin{array}{l}\text { Placing zeros in the oth- } \\
\text { er digits of the quotient }\end{array}$ & $\begin{array}{l}\text { - Correctness of } \\
\text { solution }\end{array}$ \\
\hline \multirow{2}{*}{5} & $a$ & $\begin{array}{l}\text { Pure } \\
\text { Mathematics }\end{array}$ & $\begin{array}{l}\text { Taking the maximum } \\
\text { group of quotient from } \\
\text { the corresponding dig- } \\
\text { it(s) in the dividend }\end{array}$ & $\begin{array}{l}\text { - Noticing the } \\
\text { error } \\
\text { - Explaining the } \\
\text { cause }\end{array}$ \\
\hline & $b$ & $\begin{array}{l}\text { Pure } \\
\text { Mathematics }\end{array}$ & $\begin{array}{l}\text { Detecting correct use } \\
\text { of zero in a division } \\
\text { operation }\end{array}$ & $\begin{array}{l}\text { - Noticing the } \\
\text { error } \\
\text { - Explaining the } \\
\text { cause }\end{array}$ \\
\hline
\end{tabular}

\section{Data Analysis}

The content analysis method was used while analyzing the responses of the students. Content analysis is used in cases where information that has not been previously 


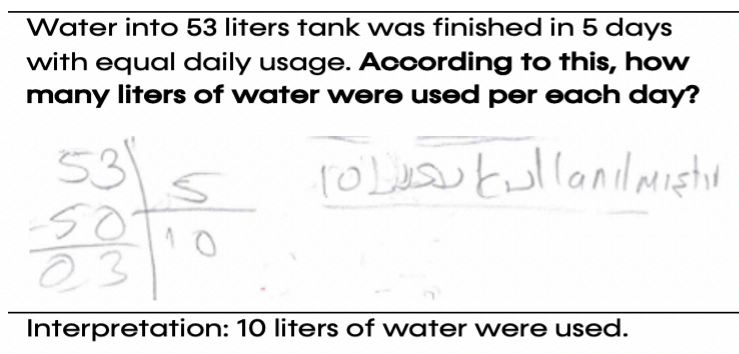

(a) Correct operation, wrong interpretation

\section{Water into 53 liters tank was finished in 5 days with equal daily usage. According to this, how many liters of water were used per each day?}

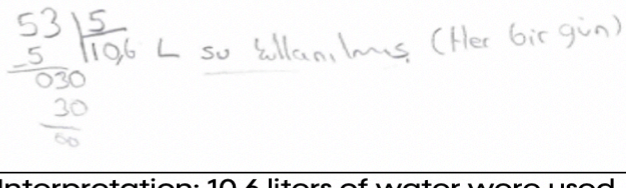

(for each day).

(b) Correct operation and interpretation

Figure 2. Sample of the coding

organized for a purpose should be systematized and digitized (Fraenkel \& Wallen, 2000). The responses of the students to the open-ended questions were coded by three independent researchers. As a result of the first coding, the reliability coefficient of the researchers was calculated as $84.6 \%$ according to the formula of Miles and Huberman (1994). The researchers negotiated and agreed on each item causing the disagreement.

The analysis of the students' answers to the first three problems requiring division with a remainder was carried out in two steps. In the first step, the strategies used by the students were determined as division, multiplication, repeated addition, repeated subtraction, and mental processing. Moreover, the strategies that do not take place in the literature regarding the realization of the division process and produce incorrect solutions are coded as incorrect strategy. Then, the frequency distributions of the students who applied the strategy steps correctly to each problem situation were obtained. In the second step, the student responses were classified according to the interpretation of the remainder in the context of the problem, true or false, and correct or incorrect operation. Then, student distributions for each problem case were determined. Figure 2 presents examples of the coding of the students' responses to the question, "The water in a 53-liter tank was finished in five days with equal amounts of use every day. How many liters of water were used each day?" Figure 2(a) presents a student's solution as the quotient of 10 and the remainder of 3 . This response was coded as a correct division process but an incorrect interpretation of the remainder and Figure 2 (b) shows the response of a student operating until there was no remainder (due to the context of the problem), which was coded as achieving the correct procedure and interpretation (Photo 1b).

The analysis of the fourth question related to the use of zero in the division process revealed that the students' responses were classified as correct or wrong, and the frequency and percentage (\%) distributions of the classifications were calculated. Finally, in the analysis of the fifth problem, in which incorrect division procedures were presented, the student responses were classified according to whether the errors made in the operations could be noticed and the reason for the error could be explained. The findings were obtained as frequency and percentage (\%) distributions.

\section{Results}

Findings concerning the strategies used in problemsolving and interpreting the remainder

Table 2 provides the strategies used by students to solve real-life problems involving division with a remainder and the number of the students who performed the selected strategy correctly.

In general, the students performed better in augmented-quotient problems than quotient-part and quotient-only problems. When the student distributions were analyzed according to the strategies, the majority

Table 2. Distribution of division strategies used in remainder problems

\begin{tabular}{|c|c|c|c|c|c|c|}
\hline \multirow[b]{2}{*}{ Division Strategies } & \multicolumn{2}{|c|}{ Quotient-part } & \multicolumn{2}{|c|}{ Augmented-quotient } & \multicolumn{2}{|c|}{ Quotient-only } \\
\hline & $\begin{array}{c}\text { Student } \\
\text { preference }\end{array}$ & $\begin{array}{l}\text { Performed } \\
\text { correctly }\end{array}$ & $\begin{array}{c}\text { Student } \\
\text { preference }\end{array}$ & $\begin{array}{l}\text { Performed } \\
\text { correctly }\end{array}$ & $\begin{array}{l}\text { Student } \\
\text { preference }\end{array}$ & $\begin{array}{l}\text { Performed } \\
\text { correctly }\end{array}$ \\
\hline Division & 58 & 29 & 49 & 37 & 49 & 38 \\
\hline Multiplication & & & 2 & 2 & & \\
\hline Repeated addition & & & 3 & 3 & 2 & 2 \\
\hline Repeated subtraction & & & & & 1 & \\
\hline Mental processing & & & 4 & 4 & 3 & 2 \\
\hline Incorrect strategy & 4 & & 3 & & 5 & \\
\hline No answer & 2 & & 4 & & 5 & \\
\hline Total & 64 & $29(45 \%)$ & 65 & $46(71 \%)$ & 65 & $42(65 \%)$ \\
\hline
\end{tabular}

Note: Some students have utilized more than one strategy during their solution process. 


\section{iejee $\sqrt{2}$}

of the students used the division algorithm. However, a small number of students used different strategies, including multiplication (Figure $3 a$ ), repeated addition (Figure 3b), mental processing (Figure 3c), and repeated subtraction (Figure $3 d$ ). It is noteworthy that students only used the division algorithm in the solution of the first problem, and some students used different strategies in addition to those who used the division algorithm in the solution of the second and third problems.

\begin{tabular}{|c|c|}
\hline $\begin{array}{l}\text { A group of } 53 \text { people will stay in a hotel with } \\
\text { rooms for } 5 \text { people. } \\
\text { According to this, what is the minimum number } \\
\text { of rooms to stay? }\end{array}$ & $\begin{array}{l}\text { A group of } 53 \text { people will stay in a hotel } \\
\text { with rooms for } 5 \text { people. } \\
\text { Acoording to this, what is the minimum } \\
\text { number of rooms to stay? }\end{array}$ \\
\hline 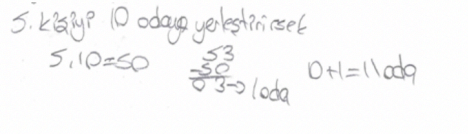 & 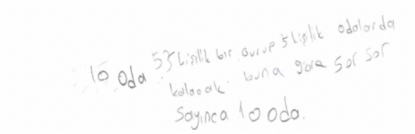 \\
\hline $\begin{array}{l}\text { Interpretation: Five people are placed in } 10 \\
\text { rooms, the remaining three people in one room, a } \\
\text { total of } 11 \text { rooms. }\end{array}$ & $\begin{array}{l}\text { Interpretation: Five people are placed in } 10 \\
\text { rooms, so if we count five by five, there will } \\
\text { be } 10 \text { rooms. }\end{array}$ \\
\hline $\begin{array}{l}\text { (a) multiplication } \\
\text { A group of } 53 \text { people will stay in a hotel with } \\
\text { rooms for } 5 \text { people. } \\
\text { Aocoording to this, what is the minimum number } \\
\text { of rooms to stay? }\end{array}$ & $\begin{array}{l}\text { (b) repeated addition } \\
\text { Triangles with } 5 \mathrm{~cm} \text { perimeters will be } \\
\text { created by using a } 53 \mathrm{~cm} \text { cable. } \\
\text { Acoording to this, how many triangles } \\
\text { can be oreated? }\end{array}$ \\
\hline & \\
\hline $\begin{array}{l}\text { Interpretation: } 11 \text { rooms but one room is empty } \\
\text { with two beds. } \\
\begin{array}{l}\text { (c) mental processing }\end{array}\end{array}$ & $\begin{array}{l}\text { Interpretation: I subtracted consecutively } \\
\text { five from 53, the result is } 11 \text { times. } \\
\text { (d) repeated subtraction }\end{array}$ \\
\hline
\end{tabular}

Figure 3. Sample division strategies adopted for the remainder questions

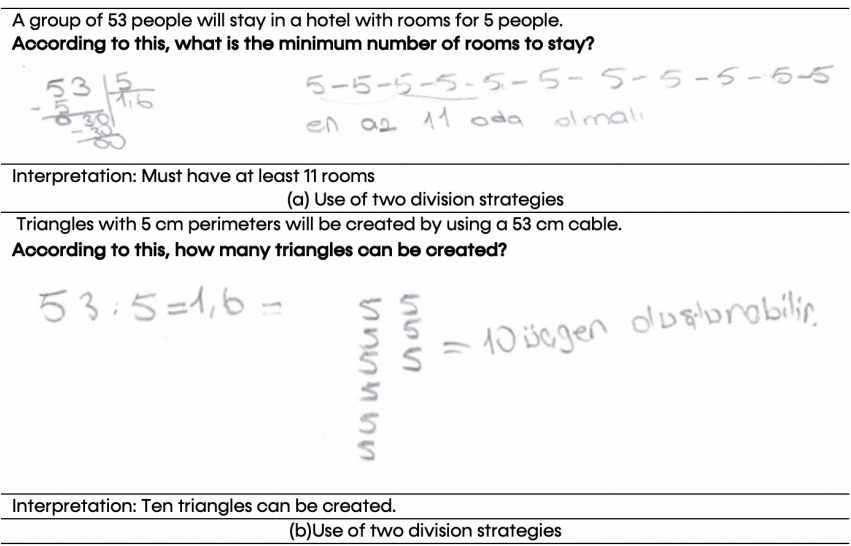

Figure 4. Uses of two different strategies

Triangles with $5 \mathrm{~cm}$ perimeters will be created by using a $53 \mathrm{~cm}$ cable. According to this, how many triangles can be created?

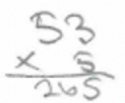

(a) Multiplying the divisor and dividend Water into 53 liters tank was finished in 5 days with equal daily usage. Acoording to this, how many liters of water were used per each day?

$$
53+5=56
$$

(b) Adding the divisor and dividend

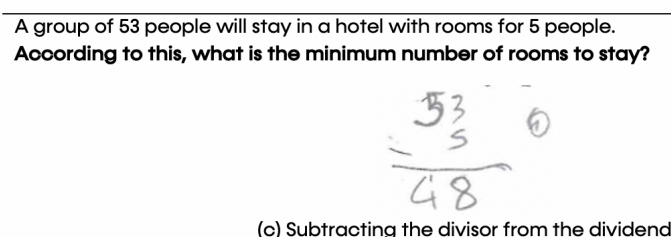

Figure 5. Mistakes in performing division strategies 
(Figure 5b), subtracting the divisor from the dividend (Figure $5 \mathrm{c}$ ), or taking no action.

When the distribution of the correct use of the division strategies was examined, at least half of the students who used the division algorithm were successful in applying the algorithm of the division process. Moreover, almost all the students who used other strategies were successful in implementing the algorithm in terms of the strategy they chose.

Table 3 presents a comparison of the results regarding students' procedural performance in the division and their interpretation skills of the results. Table 3 reveals that all the students except for one who succeeded in interpreting the remainder of the problem were also those who operated correctly. Moreover, students who were unable to conduct division correctly also could not make correct interpretation (in the context) based on their division result.

Table 3. Comparison of students' procedural and interpretation accuracy (f)

\begin{tabular}{lrrrrrrr}
\hline & $\begin{array}{c}\text { Quo- } \\
\text { tient-part }\end{array}$ & $\begin{array}{c}\text { Augmented- } \\
\text { quotient }\end{array}$ & Quotient-only \\
\hline & $\begin{array}{c}\text { Interpreta- } \\
\text { tion }\end{array}$ & Interpretation & Interpretation \\
\hline \multirow{2}{*}{ Procedure } & True & 22 & 7 & 28 & 18 & 30 & 12 \\
\cline { 2 - 8 } & False & 0 & 35 & 1 & 18 & 0 & 23 \\
\hline
\end{tabular}

\section{Findings for the Use of Zero in the Division Process}

Table 4 shows the students' awareness of the placeholder of zero as a digit. Approximately $83 \%$ of the students performed correctly in the question in which the zeros were placed at the end (digits) of the quotient while $38 \%$ of the students performed successfully in the question that required the use of zeros in the middle digits of the quotient.
Table 4. Comparison of the use of zero in the division algorithm

\begin{tabular}{lrr}
\hline & $\begin{array}{c}\text { Zeros at the end of the } \\
\text { dividend }\end{array}$ & $\begin{array}{c}\text { Zeros in other digits of } \\
\text { the quotient }\end{array}$ \\
\hline Correct & $53(83)$ & $24(38)$ \\
\hline Wrong & $11(17)$ & $40(63)$ \\
\hline
\end{tabular}

Note: Percentages were provided within parenthesis

\section{Finding and Explaining the Error in Division Operations}

Table 5 presents the students' skills of detecting and explaining errors in the division algorithm including detecting the right value of the quotient taking from the dividend and determining the correct use of zero in the division process.

Most students (69\%) answered the question prepared for the correct use of the multiplier value in the division process and realized that the division was done incorrectly. The students' approach to correcting the error in the solutions was to carry out the division process again, to reflect on the correct multiplier value in the division, or to perform the division process again after checking the solution by working backward (Figure 6). Moreover, one student noticed that there was an error in the splitting process by providing the operation, but did not provide an explanation for the cause of the error (Figure 7)

Table 5. Comparison of the students' skills to notice and explain the error given in the division process

\begin{tabular}{llll}
\hline Using the right value & $\begin{array}{l}\text { Unable to } \\
\text { explain } \\
\text { the error }\end{array}$ & $\begin{array}{l}\text { Successfully } \\
\text { explained the } \\
\text { error }\end{array}$ & Total \\
\hline Not recognizing the error & 19 & NA & 19 \\
\hline Recognizing the error & 1 & $44(69)$ & 45 \\
\hline Use of zero in the algorithm & 42 & NA & 42 \\
\hline Not recognizing the Error & 42 & $18(28)$ & 22 \\
\hline Recognizing the error & 4 & &
\end{tabular}

Note: Percentages were provided within parenthesis

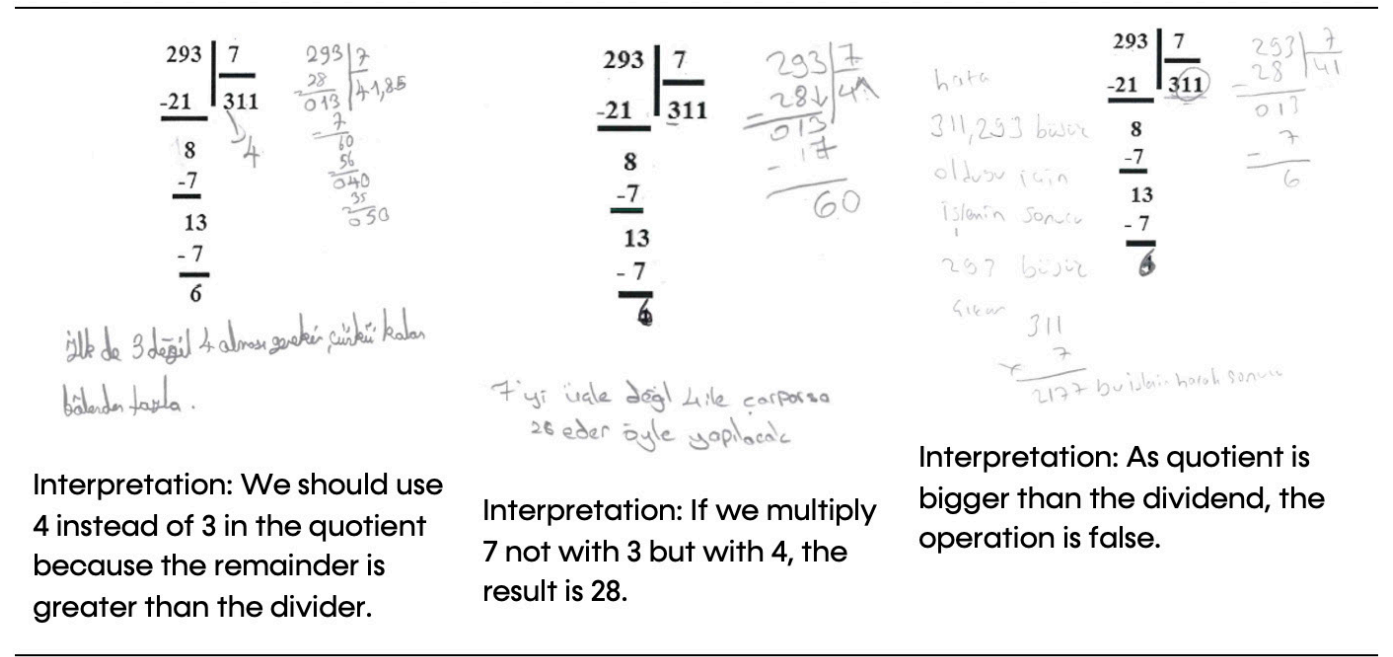

Figure 6. Students' answers explaining the reason for the error 


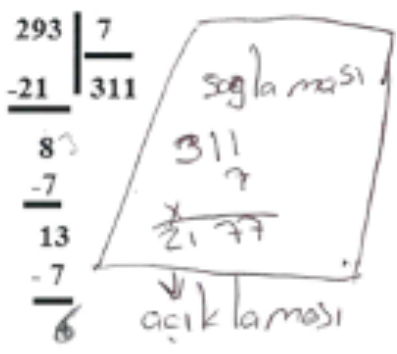

Figure 7. The answer of the student who noticed the error but could not explain it

Less than one-third of the students (28\%) realized that the solution given in the question including the use of zero in the division algorithm is incorrect (See Table 5). Students explained the reason for the error with such statements as "Since the amount of the divisor cannot be taken from the dividend number, zero must be written in the quotient. Zero must be placed in the quotient since two numbers from the dividend are taken down at the same time." (Figure 8). Four students realized the error by providing reverse operation or by stating that the quotient value was incorrect, but could not explain the reason for the error (Figure 9).

\section{Discussion and Conclusion}

This study was undertaken to reveal the ability of sixthgrade students to interpret the remainder in the division process and their procedural-conceptual knowledge about the division operation. In the study, as in the work of Silver et al. (1993), it was seen that the students who did not use the division process created solutions using alternative methods (repeated addition and repeated subtraction). When the distribution of students was examined according to the strategies used, it was seen that the majority of the students applied the division algorithm. The study by Robinson et al. (2006) on the strategies used in division indicated that the strategies could change in parallel with age; thus, fourth-grade students used repeated addition strategy and fifth to seventh graders primarily used multiplication. The authors compared their results with those of other similar studies in the literature and found that the differences in the results might be caused by the differences in the curriculum.

For the first three questions presented in the current study, the students' ability to associate everyday life and reasoning skills with the problem situation was evaluated. It was seen that even if the students undertook the process correctly, they had difficulty in interpreting the problem situation. In the study by Cain and Silver (1995), it was noted that the students provided an inappropriate solution for the problem situation by rounding quotient to the nearest natural number instead of reasoning the given situation. In Horton's (2007) study, it was indicated that the students who gave an incorrect answer did not pay attention to the expression of the problem or which type of variable was used and how this affected the solution after applying the long division algorithm. Similarly, in the work of Silver et al. (1993), it

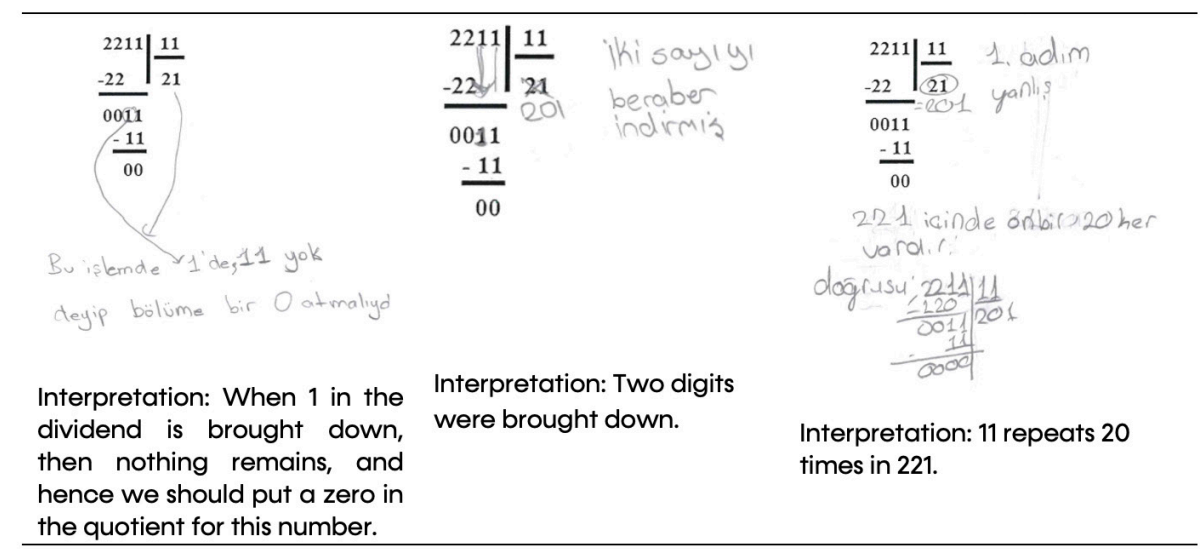

Figure 8. Student responses to the error and explaining the cause of the error

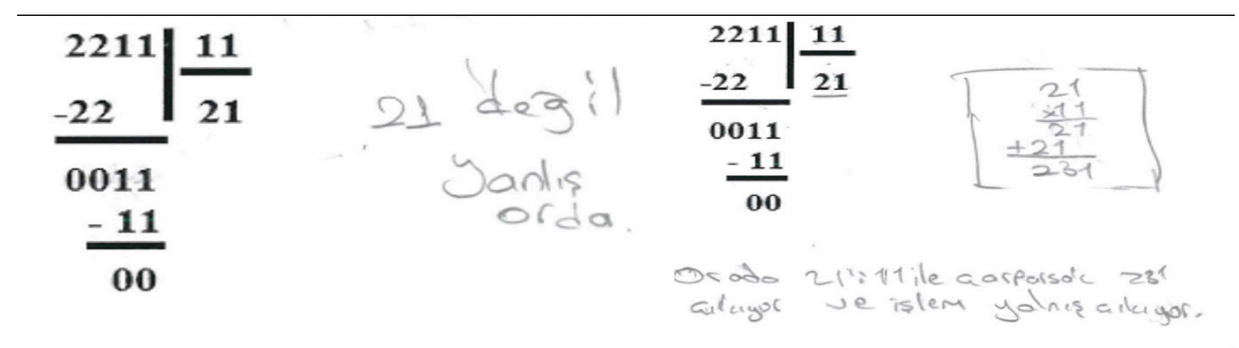

Figure 9. Student responses in failing to recognize the error and explaining the reason for the error 
was pointed out that some students did not tend to return to the story situation to comment on the problem in which they correctly performed the mathematical procedures. In the related study, the students tried to solve by considering discontinuous quantities, such as continuous and fissionable; furthermore, the problem situation was not always considered carefully. Simon (1993) examined the relationship between operational and conceptual information, between concepts (e.g., division and extraction) and between an arithmetic operation and a real-world situation, and he indicated that those categories were not discrete. Rodríguez et al. (2009) emphasized that when the students did not understand the problem, they focused on the algorithm or focused on the superficial knowledge of the problem. In general, procedural instruction leaves behind concepts, such as digit value which was placed in previous processes, and the conceptual aspects of the division process and the mathematical meaning underlying the process cannot be taught to the students (Silver \& Burkett, 1994; Martin Jr, 2009).

The current study also indicated that the students had difficulties regarding the use of zero in the long division algorithm. Lamb and Booker (2004) stated that the students did not explain why zero was placed in the answer, the placeholder of zero was not properly explained, and the students had limited conceptual knowledge in this sense. Systematic errors result from the consistent application of a faulty method, algorithm, or rule, whereas slips are unsystematic careless errors. One of the widely shared explanations for students' systematic computation errors is their flawed or weak understanding of the place value system. When the procedural aspect of computation is overemphasized without a clear conceptual understanding of the place value system, students tend not to think about the meaning of what they are doing and simply parrot someone else's directions to perform calculations (O'Brien, 1999). The traditional long division algorithm is one familiar example that many students find particularly difficult to perform with understanding. Students have also encountered problems regarding understanding (by determining the default in the solution) the division process. Some students provided explanations without providing a meaningful explanation of the place value, such as bringing down two digits requires adding zeros to the quotient. Unlike other operations, the traditional long division algorithm starts with the left-hand or larger place values, the required estimation skills often generate anxiety, and it is hard for some students to identify the magnitude of the answers that they put in each place (Fuson, 2003; Van DeWalle, 2001). This situation often leads learners or teachers to nonsensical mnemonic phrases, such as "Dirty Monkey Smells Bad" to memorize the sequence of "Divide-Multiply-Subtract-Bring it down." While memorizing these mnemonics might produce correct answers, it has no contribution to the meaningful learning of mathematics. Many educators have asserted that the essence of doing mathematics is the process of "making sense" or "figuring out" (e.g., Schoenfeld, 1991; Skemp, 2012), and 'Dirty Monkeys' alone does not contribute to this process. Unfortunately, it seems that such an approach forges its way into the classroom with little resistance. To overcome these impediments to the meaningful learning of the long division algorithm, students should be provided with the opportunities to engage in conceptually sound activities and appreciate the meaning of algorithms at the early stage, instead of relying on mechanical memorization. We must finally recognize that algorithms are fully conceptual cultural-historical products and should be taught as such (Schmittau, 2004).

\section{References}

Altun, M. (2015). Ortaokullarda (5, 6, 7 ve 8. siniflarda) matematik öğretimi.[Teaching mathematics in secondary schools (5th, 6th, 7th and 8th grades)]. Bursa: Aktüel Publishing.

Anghileri, J. (2001). A study of progression in written calculation strategies for division. Support for Learning, 16(1), 17-22.

Baki, A., \& Bütün, M. (2009). Elementary mathematics teachers' pedagogical content knowledge structures of division concept. e-Journal of New World Sciences Academy, 4(4), 1243-1256.

Baki, M. (2013). Pre-service classroom teachers' mathematical knowledge and instructional explanations associated with division. Education and Science, 38(167), 300-311.

Ball, D.L. (1990). Prospective elementary and secondary teachers' understanding of division. Journal for Research in Mathematics Education, 21(2), 132 144.

Brown, M. (1981). Number operations. In K.M. Hart (Ed.), Children's Understanding Of Mathematics (11-16). Oxford: John Murray.

Cai, J., \& Silver, E. A. (1995). Solution processes and interpretations of solutions in solving a divisionwith-remainder story problem: Do Chinese and US students have similar difficulties?. Journal for Research in Mathematics Education, 26(5), 491497.

Camos, V., \& Baumer, J. (2015). Why is it so hard to solve long divisions for 10-year-old children. International Journal of School and Cognitive Psychology, 2-7. 
Capps, L. R. (1962). Making division meaningful and logical. The Arithmetic Teacher, 9(4), 198-202.

Cornu, B. (1991). Limits. In. Tall. D. (Eds), Advanced mathematical thinking. Kluwer, Boston.

Ebby, C. B. (2005). The powers and pitfalls of algorithmic knowledge: a case study. The Journal of Mathematical Behavior, 24(1), 73-87.

Ev-Çimen, E., \& Tat, T. (2018). Investigation of eight grade students' problem posing abilities for interpretation of the remainder in division problems. Journal of Research in Education and Teaching,7(4), 1-11

Fuson, K. C. (2003). Toward computational fluency in multidigit multiplication and division. Teaching Children Mathematics, 9(6), 300-305.

Fraenkel, J.R., \& Wallen, N.E. (2000). How to design and evaluate research in education. New York, NY: McGraw-Hill.

Greer, B. (1992). Multiplication and division as models of situations. In D. A. Grouws (Ed.), Handbook of research on mathematics teaching and learning (pp. 276-295). New York: Macmillan.

Haskell, D., Pillay, A., \& Steinhorn, C. (2000). Model theory, algebra and geometry. Mathematical Sciences Research Institute Publication. 39, Cambridge University Press, NewYork

Horton, L. (2007). Understanding the Concept of Division. Doctoral dissertation, East Tennessee State University.

Işık, C., Kar, T., Işık, A., \& Albayrak, M. (2012). Investigation of primary school 6th grade students' problem posing and problem solving skills for division with remainder in natural numbers. $11^{\text {th }}$ National Primary Education Symposium, Rize.

Kaasila, R., Pehkonen, E.,\& Hellinen, A. (2010). Finnish pre-service teachers' and upper secondary students' understanding of division and reasoning strategies used. Educational Studies in Mathematics, 73(3), 247-261.

Kamii, C., \& Dominick, A. (1997). To teach or not to teach algorithms. Journal of Mathematical Behaviour, 16(1), 51-61.

Khan, F. A. (2004). Living, learning and doing mathematics: a study of working-class children in Delhi. Contemporary education dialogue, 1(2), 199-227.
Lamb, J., \& Booker, G. (2004). The impact of developing teacher conceptual knowledge on students' knowledge of division. In M. J. Hoines, \& A. B. Fuglestad (Eds), Proceedings of the 28th International Group for the Psychology of Mathematics Education Conference (Vol. 3, pp. 177-182). Bergen: PME

Lee, J. E. (2007). Making sense of the traditional long division algorithm. The Journal of Mathematical Behavior, 26(1), 48-59.

Leung, I., Wong, R., \& Pang, W. S. (2006). Departing from the traditional long division algorithm: An experimental study.

Martin Jr, J. F. (2009). The goal of long division. Teaching Children Mathematics, 15(8), 482-487.

Mclntosh, A., Reys, B. J., \& Reys, R. E. (1992). A proposed framework for examining basic number sense. For The Learning Of Mathematics, 12(3), 2-44.

Merriam, S.B. (1998). Qualitative Research and Case Study Applications in Education. Jossey-Bass Publishers, San Francisco.

Miles, M. B., \& Huberman, A. M. (1994). Qualitative data analysis: A sourcebook. Beverly Hills: Sage Publications.

O'Brien, T. C. (1999). Parrot math. Phi Delta Kappan, 80, 434-438.

Önal, H., \& Aydın, O. (2018). Misconceptions and error patterns mathematics lesson in primary school. Journal of Educational Theory and Practice Research, 4(2), 1-9.

Parmar, R. S. (2003). Understanding the concept of "division": Assessment considerations. Exceptionality, 11(3), 177-189.

Pope, S. (2012). The Problem with Division. Mathematics Teaching, 231, 42-45.

Robinson, K. M., Arbuthnott, F.D., \& Gibbons, K.A.(2002). Adults' representations of division facts: A consequence of learning history. Canadian Journal of Experimental Psychology, 56, 302-309.

Robinson, K. M., Arbuthnott, K. D., Rose, D., McCarron, M. C., Globa, C. A., \& Phonexay, S. D. (2006). Stability and change in children's division strategies. Journal of Experimental Child Psychology, 93, 3, 224-238. 
Rodríguez, P., Lago, M. O., Hernández, M. L., Jiménez, L., Guerrero, S., \& Caballero, S. (2009). How do secondary students approach different types of division with remainder situations? Some evidence from Spain. European Journal of Psychology of Education, 24(4), 529.

Sarwadi, H. R. H., \& Shahrill, M. (2014). Understanding students' mathematical errors and misconceptions: The case of year 11 repeating students. Mathematics Education Trends and Research, 2014(2014), 1-10.

Schmittau, J. (2004). Vygotskian theory and mathematics education: Resolving the conceptual-procedural dichotomy. European Journal of Psychology of Education, 19(1), 19-43.

Schoenfeld, A. H. (1991). On mathematics as sensemaking: An informal attack on the unfortunate divorce of formal and informal mathematics. In D. N. Perkins; J. Segal, \& J. Voss (Eds.), Informal reasoning and education. Hillsdale, NJ: Erlbaum.

Silver, E. A. (1988). Solving story problems involving division with remainders: The importance of semantic processing and referential mapping. In M. J. Behr, C. B. Lacampagne, \& M. M. Wheeler (Eds.), Proceedings of the tenth annual meeting of the North American Chapter of the International Group for the Psychology of Mathematics Education (pp. 127-133). DeKalb, IL: Northern Illinois University

Silver, E. A., Mukhopadhyay, S., \& Gabriele, A. J. (1992). Referential mappings and the solution of division story problems involving remainders. Focus on Learning Problems in Mathematics, 14(3), 29-39.

Silver, E. A., Shapiro, L. J., \& Deutsch, A. (1993). Sensemaking and the solution of division problems involving remainders: An examination of students' solution processes and their interpretations of solutions. Journal for Research in Mathematics Education, 24, 11

Silver, E. A., \& Burkett, M. L. (1994). The Posing of Division Problems by Preservice Elementary School Teachers: Conceptual Knowledge and contextual Connections.

Simon, M. A. (1993). Prospective elementary teachers' knowledge of division. Journal of Research in Mathematics Education, 24, 233-254.

Skemp, R. R. (2012). The psychology of learning mathematics: Expanded American edition. Routledge.
Van de Walle, J. A. (2001). Elementary and middle school mathematics: Teaching developmentally (4th ed.). NewYork: Longman.

Varol, F., \& Kubanç, Y. (2015). Requiring students to beat the experienced by the verbal and arithmetic division operation investigation of problems. Ondokuz Mayis University Journal of Faculty of Education, 34(1), 99-123.

Yenilmez, K., \& Dere, D. (2018). Examination of the fifth grade students' interpretation remainder in the division operation. Journal of Research in Education and Teaching, 7(2), 92-104.

Yıldırım, A., \& Şimşek, H. (2005). Sosyal bilimlerde nitel araştırma yöntemleri (5. basım) [Qualitative research methods in social sciences (5th ed.)]. Ankara: Seçkin Publishing

Yin, R.K. (2003). Case Study Research: Design and Methods. Sage. Thousand Oaks, California.

Yorulmaz, A. (2018). The impact of realistic mathematics education on correcting the mistakes in number operations skills of fourth grade primary school students. Doctoral dissertation, Marmara University Institute of Educational Sciences, İstanbul. 